Soil Science Society of America Journal 71(5) 1516-1523

Authors' PrePrint Version

\title{
Sediment Retention by a Stiff Grass Hedge under Subcritical Flow Conditions
}

\author{
Janet Hussein ${ }^{* 1}$, Hossein Ghadiri ${ }^{1}$, Bofu $\mathrm{Yu}^{2}$ and Calvin Rose ${ }^{1}$ \\ ${ }^{1}$ Australian Rivers Institute, Griffith School of Environment, Griffith University, Nathan Campus, 170 Kessels Rd, \\ Nathan, 4111, Queensland, A ustralia. \\ ${ }^{2}$ Centre for Environmental Systems Researc, h Griffith University, Nathan Campus, 170 Kessels Rd, Nathan, \\ 4111, Queensland, A ustralia.
}

* Corresponding author: Phone (617) 37356744 Fax (617) 37357459 Email: j.hussein@griffith.edu.au

\begin{abstract}
Reduction of diffuse fluxes of sediments from catchments is frequently achieved through use of vegetative buffers, but the dynamics of this reduction are not fully understood. The physical processes involved in sediment deposition by a stiff grass buffer (hedge) at a low, subcritical, flow rate were therefore examined. Flow experiments were carried out in the Griffith University Tilting-Flume Simulated Rainfall facility using a $0.3 \mathrm{~m}$ width, vetiver hedge (Vetiveria zizaniodes L., sterile cultivar Monto) at $5 \%$ slope. Sediments comprising a sandy soil (Podzol) and red clay (Ferralsol) were introduced into the flow upstream of the buffer and the resultant hydrology, sediment deposition and outflow characteristics were measured. Flow retardation produced a backwater upstream of the vetiver hedge and sediment deposition varied with soil type in this backwater. The backwater region was greatly extended by the deposition process, increasing overall sediment trapping efficiency. Buffering action reduced mean sediment loads in the outflow to $3.2 \%$ and $6.0 \%$ of the inflow concentration for the Podzol and Ferralsol, respectively, with a significant difference $(\mathrm{P}<0.01)$ between the soils. In contrast to other buffer research where deposited sediments were coarsest upstream of the backwater, we found the coarsest particles at the downstream end for the Podzol and Ferralsol, indicating possible bedload movement in addition to the deposition/entrainment processes that dominate supercritical flow. The type of flow therefore affects the size distribution as well as the amount and efficiency of sediment deposition in front of vetiver hedges.
\end{abstract}

\section{Abbreviations:}

ARC, Australian Research Council; CEC, cation exchange capacity; EC, electrical conductivity; ESP, exchangeable sodium percentage; GUTSR, Griffith University Tilting-flume Simulated Rainfall facility; MWD, mean weight diameter; PVC, polyvinyl chloride;.

\section{Acknowledgements}

The buffer strip work is funded by an ARC Discovery Project Grant (DP0451654). The authors wish to thank Joe McMahon and Hapsara Mahardhika for assistance with the flume experiments, Mr Aubrey Chandica for help with the digitisation and Dr Paul Truong for sourcing and providing information on vetiver. 


\section{INTRODUCTION}

Vegetative buffer strips are widely employed as a conservation measure to reduce fluxes of sediments and associated pollutants from overland flow in catchments. The buffers reduce sediment and associated pollutants through a combination of settling, infiltration, and adhesion processes (Newham et al., 2005). The energy state of overland flow is classified by the Froude number, which shows how the flow reacts to perturbations in the bed. These perturbations, or changes in elevation of the bed, produce changes in energy per unit weight (or total head) of the flow (Finnemore and Franzini, 2001). When buffers retard flow, they produce a backwater (a ponded zone) with tranquil subcritical flow (Froude number $<1$ ), or a zone of hydraulic adjustment (Froude number $>1$ ) for rapid supercritical flow (Rose et al., 2002). The decrease in flow velocity in these zones leads to deposition of incoming sediments upstream of the buffer, thus reducing the flux through the buffer and potential movement into water bodies. Because larger particles settle faster than finer ones, the deposited sediment tends to be coarser in size than the inflow sediment and some fine particles preferentially move through the buffer (Dabney et al, 1995; Meyer et al., 1995; Ghadiri et al., 2001).

The flow and sediment transport through buffers have been investigated by a number of researchers (Dabney et al., 1995; Gilley et al., 2000; Ghadiri et al., 2001; Rose et al., 2003; Blanco-Canqui et al., 2004a, b). There are a number of variables which can affect the sediment-trapping efficiency of buffers, including the type and width of vegetation used. Buffers comprising tall, erect, grass strips are sometimes called hedges, or barriers. These are commonly $<1 \mathrm{~m}$ in width and are particularly effective in decreasing fluxes due to the settling of sediments. Narrow grass hedges thus primarily reduce pollutant loads due to the settling of particulate-sorbed nutrients such as nitrogen and phosphorus. Vetiver and switchgrass (Panicum virgatum) are often used for this kind of hedge as they have a dense upright growth pattern with strong rooting systems and can withstand high flow depths up to $600 \mathrm{~mm}$ (Truong, 1999; Metcalf et al., 2003; Blanco-Canqui et al., 2004a). Shorter grasses may be just as effective as the taller grasses at low flow depths, but these can be easily overtopped at higher flows. 
Thus, tall hedges may be more practical as they require less land area to achieve a good effect, irrespective of the flow regime. Vetiver grass and switchgrass are usually more efficient in trapping sediment (Meyer et al., 1995) than others such as eulalia (Miscanthus sinensis) and tall fescue (Festuca arundinacae) due to their strong, erect leaves/culms. Several flume studies have shown that grass widths as narrow as $20 \mathrm{~cm}$ are effective in trapping sediment at unit surface flow rates $>0.01 \mathrm{~m}^{2} \mathrm{~s}^{-1}$ (Dabney et al., 1995; Meyer et al., 1995), and Ghadiri et al. (2001) found that when the width of a grass buffer was increased from 20 to $40 \mathrm{~cm}$, there was no increase in sediment deposition. In a field study, BlancoCanqui et al. (2004a) reported that sediment reduction by a $0.7 \mathrm{~m}$ switchgrass hedge was equivalent to a $4 \mathrm{~m}$ wide fescue buffer. Therefore, substantial increases in width of stiff grass hedges in the field are only likely to achieve relatively small increases in sediment trapping, primarily through increased infiltration rather than sediment settling.

Slope, flow rate, and sediment type and concentration can also affect sediment trapping efficiency. Dabney et al. (1995) showed that finer sediments were less efficiently deposited by the hedges than coarse sediments, while Meyer et al. (1995) demonstrated that changing sediment concentration from 3.5 to $7 \%$ had little effect on sediment trapping. Increased flow rate tended to decrease sediment trapping (Meyer et al., 1995) but this varied with sediment type. Ghadiri et al. (2001) found that for a given grass density and flow rate, sediment deposition increased with slope, mainly due to the higher sediment concentration of the runoff, prior to entering the backwater. Clearly, there are a number of interacting variables which affect the sediment-trapping efficiency of grass hedges. To provide sound field recommendations for design and management of these hedges for different sediment types, flow conditions and slopes, a more thorough understanding of the sediment deposition processes involved is required.

Most of the detailed, process-based, research on buffers has been carried out in flumes. Typically supercritical flows with high unit flow rates $>0.01 \mathrm{~m}^{2} \mathrm{~s}^{-1}$ and Froude numbers $>2$ were imposed upstream (Dabney et al., 1995; Meyer et al.,1995; Dalton, 1997; Ghadiri et al., 2001; Metcalf et al., 2003). In contrast, much of the field work on runoff plots with buffers has been conducted at lower flow rates. For 
example, Gharabaghi et al. (2000) examined surface flow rates of 0.00025 to $0.0017 \mathrm{~m}^{2} \mathrm{~s}^{-1}$, while Blanco-Canqui et al. (2004a) measured runoff flow rates of $0.0001 \mathrm{~m}^{2} \mathrm{~s}^{-1}$ (from applied rainfall of $55 \mathrm{~mm}$ $\mathrm{h}^{-1}$ ). In shallow overland flow, typically developed from low to medium intensity storms on low slopes, the characteristic dimensions of surface roughness elements are comparable to and often larger than the flow depth itself (Barros et al., 2001). Emmett (1978) noted that Froude numbers $>0.2$ are not encountered on natural hillslopes and thus concluded that overland flows are mostly subcritical. Barros et al. (2001) similarly found that Froude numbers did not exceed 0.2 for flows $\left(0.0005\right.$ to $\left.0.001 \mathrm{~m}^{2} \mathrm{~s}^{-1}\right)$ on various surfaces comprising stones over two soil types or over an impervious base. Our experiments therefore focused on subcritical flow (Froude numbers $<1$ ) with upstream flow depths (before the backwater) of less than $10 \mathrm{~mm}$.

Current erosion/deposition theory (mainly derived from research on faster, supercritical, flows and assuming static flow and bed conditions) suggests that the coarser material should drop out of suspension furthest away from the grass hedge at the starting position of the backwater, where flow velocity first begins to decrease and the settling velocities of the coarser particles are no longer exceeded. As deposition occurs however, conditions change to non-steady-state and flow depths may become shallower with greater stream power, thus coarse sediment could be deposited nearer the buffer. However, Dabney et al. (2005) reported the coarsest material was deposited furthest upstream using supercritical flow conditions. Hussein et al. (2006), using subcritical flows in flume experiments, observed coarse sediment particles rolling over the surface of the bed towards the hedge, creating a particle size distribution opposite to that reported by Dabney et al. (1995). Sediment deposits were thus coarser towards the hedge. Therefore, our general objective was to examine the deposition of sediment induced by a vetiver grass hedge from subcritical surface flow and to compare these data to similar suband supercritical flow experiments elsewhere. The specific objectives were to measure sequential water and sedimentation profiles, together with outflow sediment characteristics, for two contrasting sediments under subcritical flow conditions in the Griffith University Tilting-flume simulated Rainfall Facility (GUTSR). 


\section{MATERIALS AND METHODS}

\section{Description and Analyses of Soils}

Two Australian soils of contrasting texture were used for this study; a brown sandy soil, classified as an Orthod (Soil Survey Staff, 1999) or a Podzol (FAO, 1998) from the Toohey Forest area in Brisbane $\left(27^{\circ} 35^{\prime} \mathrm{S} ; 153^{\circ} 05^{\prime} \mathrm{E}\right)$ and a red clay classified as a Udult (Soil Survey Staff, 1999) or a Ferralsol (FAO, 1998) from Redlands Bay Research Station in Brisbane (27 37'S; $\left.153^{\circ} 19^{\prime} \mathrm{E}\right)$.

Basic chemical and physical properties were determined on the two soils (Table 1). Soil particle size distributions were determined by the hydrometer method (Australian Standards, 1995). Soil pH and electrical conductivity (EC) were measured at a 1: 5 ratio using a conductivity meter. Exchangeable cations were determined using the rapid ammonium acetate extraction method at $\mathrm{pH} 7$ and corrected for soluble salts using saturation extracts (Rayment and Higginson, 1992) and exchangeable acidities were measured using the $\mathrm{KCl}$ method (Rayment and Higginson, 1992). Cation exchange capacities (effective CEC) were determined by adding the exchangeable bases to the exchangeable acids. The exchangeable sodium percentage (ESP) was calculated using the exchangeable sodium expressed as a percentage of the CEC.

Mean weight diameters (MWD) of the inflow sediments in the flume were determined by wet sieving of four replicate samples collected in $600 \mathrm{~mL}$ beakers from the dispenser, using the method described in Ghadiri et al. (2001), with sieves of mesh size 2.00, 1.00, 0.50, 0.25, 0.106 and $0.053 \mathrm{~mm}$. MWDs were calculated according to Van Bavel (1950) as:

$$
M W D=\sum x_{i} f_{i}
$$

where $x_{i}$ is the arithmetic mean diameter of each size fraction and $f_{i}$ is the fraction of the total sample mass occurring in each size fraction. Sediment $<0.053 \mathrm{~mm}$ was collected during the wet sieving process and later analysed by sedimentation in a 1 litre cylinder using a pipette. The $<0.053 \mathrm{~mm}$ sediment dry weight was determined by adding the pipette sample weights to the weight of sediment remaining in the cylinder. The total sediment weight was then summed over all the size fractions and divided by the 
volume of the inflow sample to give a sediment concentration corrected to a 1 litre basis $\left(\mathrm{g}^{-1}\right)$. The wet aggregate densities were estimated from percent sand ( $>0.02 \mathrm{~mm}$; Loch and Rosewell, 1992), giving values of 2500 and $1600 \mathrm{~kg} \mathrm{~m}^{-3}$ for the Podzol and Ferralsol, respectively. The settling velocities of the inflow sediment were then calculated from size class data (wet sieving) and the wet aggregate densities, employing the equation of Cheng (1997).

Table 1. Selected physical and chemical properties of the two soils used in the experiments Property Podzol Ferralsol

$\begin{array}{lcc}\text { Physical } & & \\ \text { Sand }(2.00-0.02 \mathrm{~mm}), \mathrm{g} \mathrm{kg}^{-1} & 901 & 360 \\ \text { Silt }(0.02-0.002 \mathrm{~mm}), \mathrm{g} \mathrm{kg}^{-1} & 41 & 210 \\ \text { Clay }(<0.002 \mathrm{~mm}), \mathrm{g} \mathrm{kg}^{-1} & 57 & 430 \\ \text { Soil textural class } & \text { Sand } & \text { Clay } \\ \text { Mean settling velocity of inflow sediment, } \mathrm{m} \mathrm{s}^{-1} & 0.0439 & 0.0365 \\ \text { Mean weight diameter of inflow sediment, mm } & 0.488 & 0.883 \\ \text { Chemical } & & \\ 1: 5 \mathrm{pH} \text { in } \mathrm{CaCl}_{2} & 5.2 & 5.3 \\ \text { Electrical conductivity of } 1: 5 \text { suspension, } \mathrm{mS} \mathrm{m}^{-1} & 0.51 & 0.64 \\ \text { Exchangeable Ca, cmol } \mathrm{kg}^{-1} & 5.8 & 8.7 \\ \text { Exchangeable } \mathrm{Mg}, \mathrm{cmol}_{\mathrm{c}} \mathrm{kg}^{-1} & 3.6 & 6.5 \\ \text { Exchangeable Na, cmol } \mathrm{kg}^{-1} & 0.2 & 0.2 \\ \text { Exchangeable } \mathrm{K}, \mathrm{cmol}_{\mathrm{c}} \mathrm{kg}^{-1} & 0.1 & 0.1 \\ \text { Cation Exchange Capacity, cmol } \mathrm{kg}^{-1} & 9.7 & 15.7 \\ \text { Exchangeable Sodium Percentage } & 2.0 & 1.3 \\ & & \end{array}$

The Podzol is much coarser than the clay textured Ferralsol, consisting primarily of coarse sand-size particles with little aggregation. The settling velocity of the inflow sediment $(<4.76 \mathrm{~mm}$ sieved soils) was greater for the Podzol than the Ferralsol. However, the Ferralsol had an unexpectedly high settling velocity due to the preponderance of large stable aggregates in the soil. These have formed as a result of the inert clay fraction and high iron oxide content of the soil (14\% dithionite extractable; Black and Waring, 1976). The textural differences are reflected in the chemical properties of the soils with the Ferralsol having the larger CEC and exchangeable cation content. Exchangeable Sodium Percentage (ESP) and EC values were low to moderate for both soils, indicating small amounts of soluble salts and relatively low sodium levels, respectively.

\section{Flume Experiments}

The GUTSR consists of a $5.8 \mathrm{~m}$ long, $1 \mathrm{~m}$ wide flume, of adjustable slope (Ghadiri et al., 2001). Experiments were carried out in a 0.3 by $3.5 \mathrm{~m}$ section constructed within the flume. For the flume 
experiments, $0.3 \mathrm{~m}$ wide, dense vetiver hedges were grown in planting boxes. Prior to transferring a hedge to the flume, the entire root system was dipped into a Plaster of Paris mixture (calcium sulphate hemihydrate and water mixed in a 1:1 ratio) to prevent sediment washoff from the root bed and to give firm anchorage to the plants, similar to that experienced by deeply rooted vetiver in the field. The completed hedge was thus $0.3 \mathrm{~m}$ in width (to fit across the flume) and $0.3 \mathrm{~m}$ in length (along the flow path of the flume) with a stem/culm density of $4300 \mathrm{stems}^{-2}$. Average stem/culm width was $9 \mathrm{~mm}$ at $30 \mathrm{~mm}$ height. The completed length was similar to that of a vetiver strip in arable fields after $\sim 1$ year of growth (Dalton, 1997). The hedge was inserted in the flume (Fig.1) and a raised flume surface was constructed level with the base of the plants, and on either side of the hedge, using impermeable boards. To simulate a rough soil surface, the faces of the boards were covered using a rough material with a Manning's roughness coefficient of 0.04. As the boards and hedge base were impermeable in the GUTSR, sediments were removed from flow by settling alone.

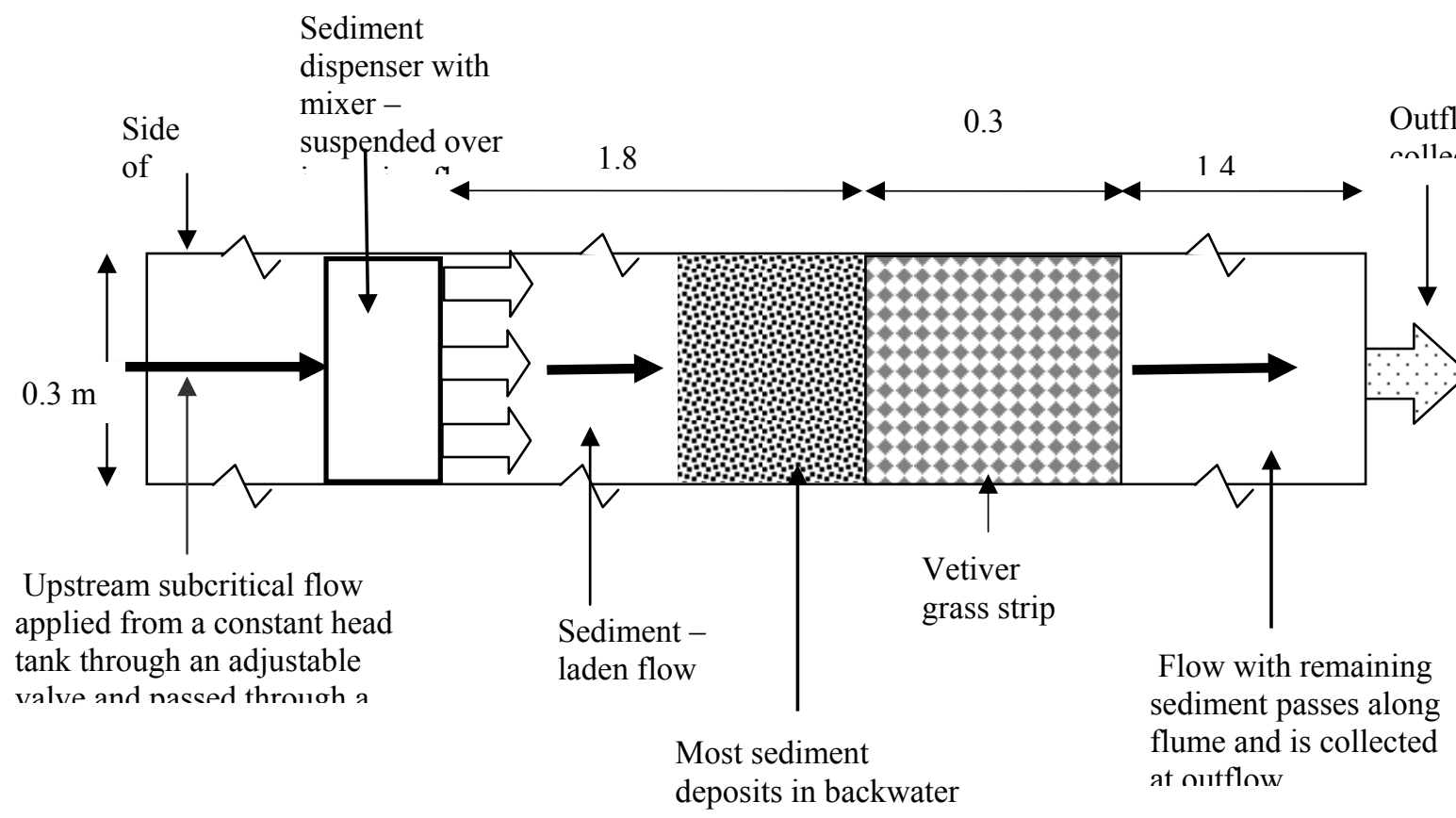

Fig. 1. An overhead view of the Griffith University Tilting-Flume facility (GUTSR) showing experimental layout 
Three replicate experiments were conducted for each soil at $5 \%$ slope. A unit flow rate of 0.001 $\pm 0.00003 \mathrm{~m}^{2} \mathrm{~s}^{-1}$ was applied $1.8 \mathrm{~m}$ upstream of the vetiver hedge, through a dispenser, with an average flow depth of $8.0 \pm 0.5 \mathrm{~mm}$ upstream of the backwater region. After stabilization of flow, the water surface elevations upstream and downstream of the vetiver hedge were recorded using thin rigid PVC strips impregnated with water-soluble potassium permanganate dye, inserted into, and parallel to, the flow in the centre of the flume (Ghadiri et al., 2001; Rose et al., 2003). The water dissolved the dye leaving a sharp watermark. The PVC strips were then dried and photocopied and the water depths digitised from the photocopies. Outflow rate was assessed from the volume of outflow collected in a bucket in unit time. The soils were then introduced as slurry into the surface flow through the dispenser (Fig.1). The dispenser comprised a plastic container (height $15 \mathrm{~cm}$, length $15 \mathrm{~cm}$ and width $30 \mathrm{~cm}$ ) with 3 adjustable outlet taps at the base. The flow was maintained at the same total flow rate identified previously by adjusting the inflow rate. The loose slurry was prepared by adding $200 \mathrm{~mL}$ of water to $90 \mathrm{~g}$ air dry soil (sieved $<4.76 \mathrm{~mm}$ ) in each of 40 beakers. The soils had little organic debris and any obviously large pieces $>10 \mathrm{~mm}$ were removed, prior to sieving. Wetting was done two hours prior to each run, followed by stirring, to ensure full saturation/swelling of the soil. The slurry was then added to the dispenser from the containers, every minute over a 40 minute period, giving an inflow concentration of $4.7 \mathrm{~g} \mathrm{~L}^{-1}$. The sediment was continuously agitated in the dispenser with an electric mixer, to ensure an even distribution of sediment into the flow. A similar set of experiments for a Vertisol were carried out at 1, 3 and 5\% slopes (Hussein et al., 2006). The results of the 5\% slope experiments on the Vertisol will later be compared with results from the Podzol and Ferralsol soils in this study, to highlight differences in sediment behaviour due to textural differences. All experimental conditions were the same for the Vertisol, except that slurry was added at twice the concentration for half the period of time (20 minutes). The total added slurry amounts were therefore the same for all three soils.

Outflow samples were collected in $600 \mathrm{~mL}$ beakers at 2 minute intervals during each run and sediment concentrations $\left(\mathrm{g} \mathrm{L}^{-1}\right)$ were determined by oven drying. Larger outflow samples were 
collected in buckets over a $20 \mathrm{~s}$ period, at 4 minute intervals, to yield outflow rates together with sediment whose components were analysed for particle size distribution. The rate of sediment deposition in front of the vetiver hedge was estimated using small zinc tags $(20 \times 20 \times 1 \mathrm{~mm})$ which were introduced into the flow, on top of depositing sediment, at different distances upstream of the hedge. The tags were introduced every 8 minutes. At the end of the sediment addition, the elevation of the new water surface was again measured, using dyed PVC strips. After flow ceased, the surface elevation of the sediment both across and along the flume was photographed, then measured using dyed PVC strips. Depths to the tags embedded in the sediment were also recorded, and then samples of the sediment were taken from different distances upstream of the vetiver hedge. The deposited sediment samples were analysed for aggregate/particle size distribution by wet sieving and pipette analysis. Four replicate cores were taken from the wet deposited sediments immediately after completion of each experiment to determine bulk density. Cores were obtained using thin aluminium samplers $(48 \mathrm{~mm}$ diam.) from the deepest part of the deposited sediment (average $2-3 \mathrm{~cm}$ in thickness). The total volumes of deposited sediments were determined from the sum of sediment depths at $2.5 \mathrm{~cm}$ distances along the flume multiplied by flume width. The volumes were then multiplied by the relevant bulk densities to give total masses of deposited sediment.

\section{Statistics}

Statistical t-tests (at the 5\% level) were used to test the hypothesis that there was no difference between the mean data values measured for the Podzol and Ferralsol.

\section{RESULTS AND DISCUSSION}

\section{Water Profiles}

The digitised data on flow/deposited sediment depths were recorded on charts, as illustrated in Fig. 2 for one of the Ferralsol replicates. Upstream distances from the start of the vetiver hedge are presented as positive values. Flow depths were corrected relative to $0 \mathrm{~mm}$ elevation, at the start of the vetiver 
hedge. The 'water start' line in Fig. 2 shows the water profile depths at the start of the experiment (before addition of sediment) and indicates that the grass hedge retarded flow, causing a backwater or 'ponded' area with an increased flow depth immediately upstream of the vetiver hedge. Initial flow depths upstream of the backwater $(1.25$ to $1.0 \mathrm{~m})$ ranged from $7-8 \mathrm{~mm}$ and flow rates were subcritical, with Froude numbers of $0.59 \pm 0.04$. Flow depths inside the vetiver hedge could not be reliably recorded due to the thick foliage of the grass. After the hedge, flow depths decreased to $5-8 \mathrm{~mm}$ as there was no further resistance to flow. A maximum flow depth of $27 \mathrm{~mm}$ was recorded just upstream of the vetiver hedge (see 'water start' at $0 \mathrm{~m}$; Fig. 2) and the backwater zone extended $0.50 \mathrm{~m}$ (upstream) of the vetiver hedge for this experiment. Upon the addition of sediment, deposition occurred in the ponded zone due to reduced flow velocity. Larger particles/aggregates with high settling velocities were therefore deposited in the backwater region. The sediment reached a final maximum height of $\sim 13 \mathrm{~mm}$ at $0.4 \mathrm{~m}$ upstream of the vetiver hedge (Fig. 2) and extended upstream to $0.8 \mathrm{~m}$. Flow depth over this deposited sediment reached a maximum recorded value of $40 \mathrm{~mm}$ at the start of the vetiver hedge ('water end' $0 \mathrm{~m}$; Fig. 2). The backwater zone thus grew in length and height due to net deposition, extending upstream to a final value of $0.9 \mathrm{~m}$.

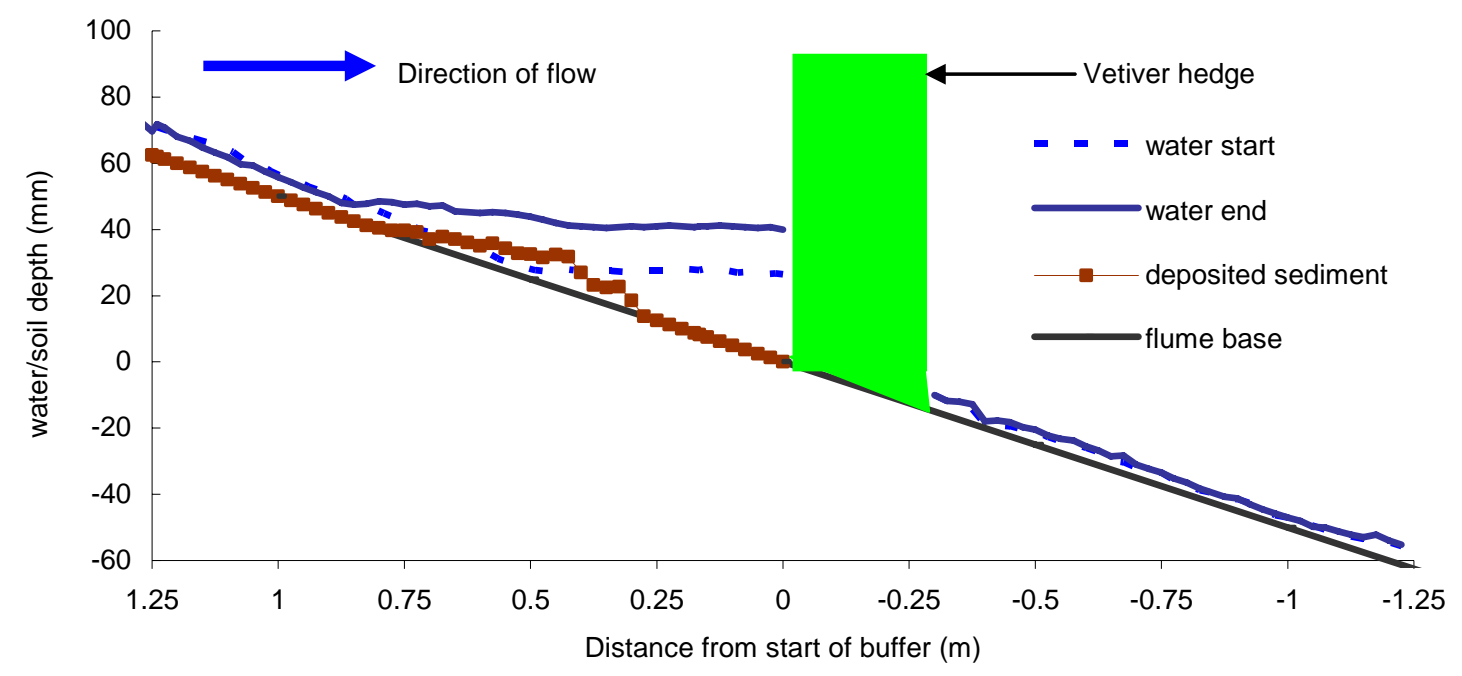

Fig. 2. Water and sediment depths in the flume at different times for the Ferralsol at 5\% slope. Experiment duration was 40 minutes. 
Water profiles were similar for both soils at the beginning of the experiments. Backwater depths were at a maximum at the start of the vetiver hedge and mean depths were $32 \pm 3 \mathrm{~mm}$ increasing to $41 \pm 4 \mathrm{~mm}$ at the end of the experiment. The maximum backwater depths measured in our experiments, prior to sediment addition, were about four times the initial flow depth (upstream of the start of the backwater at $1.25-1.0 \mathrm{~m}$ ). In contrast, Ghadiri et al. (2001) noted that the maximum backwater depths in their flume experiments with nail beds were about 2 to 3 times the initial flow depths. This difference is probably due to the increased flow resistance offered by the vetiver hedge in contrast to the nail beds tested by Ghadiri et al. (2001), using nails of $2.8 \mathrm{~mm}$ diameter. The water depths we recorded, however, were considerably lower than those of Dabney et al. (1995) due to the lower flow rates used in our experiments. The backwater depths in our experiments were somewhat similar to measurements in some field studies, where subcritical flow conditions were operating. Blanco-Canqui et al. (2004b) reported a maximum ponding depth of $30 \mathrm{~mm}$ for a $0.7 \mathrm{~m}$ switchgrass/fescue hedge at $\sim 5 \%$ slope and 66 $\mathrm{mm} \mathrm{h}^{-1}$ applied rainfall, giving an outflow rate of $0.000122 \mathrm{~m}^{2} \mathrm{~s}^{-1}$. The backwater depth is fairly similar to our data, although their flow rate was lower. However, the increased thickness of the strip possibly provided greater resistance than the $0.3 \mathrm{~m}$ vetiver used in our experiment.

Table 2. Length of backwaters at start and end of the experiments and relative sediment concentrations in the outflow sediment for the two soils. (Mean \pm standard error)

\begin{tabular}{lll}
\hline Parameter & Podzol & Ferralsol \\
\hline Start of backwater at beginning of experiment, $\mathrm{m}$ & $0.52 \pm 0.10$ & $0.57 \pm 0.09$ \\
$\begin{array}{l}\text { Start of backwater at end of experiment, } \mathrm{m} \\
\text { Increase in length of backwater (upstream) due to }\end{array}$ & $1.07 \pm 0.08$ & $0.90 \pm 0.06$ \\
deposition, m & & 0.33 \\
& & \\
\hline $\begin{array}{l}\text { Mean sediment concentration in outflow g L } \\
\text { Mean sediment in the outflow as a percentage of }\end{array}$ & $0.15 \pm 0.02$ & $0.28 \pm 0.09$ \\
$\begin{array}{l}\text { inflow concentration } \\
\text { Mean percentage of sediment trapped before outflow }\end{array}$ & 96.8 & $6.0 \pm 0.44$ \\
\hline
\end{tabular}

While all the backwaters started at a similar position, there was a significant difference $(\mathrm{P}<0.1)$ in the length of the backwater at the end of the experiments for the two soils (Table 2), with the length increasing by 0.55 and $0.33 \mathrm{~m}$ for the Podzol and Ferralsol, respectively. The backwater for a Vertisol reported in Hussein et al. (2006) increased by only $0.22 \mathrm{~m}$ at the same slope. Thus as coarseness of the input sediment increased, the backwater zone extended further upstream. This was due to the varying positions of sediment deposition, which are discussed in the next section 


\section{Sediment Deposition}

Sediments were primarily deposited in a low mound upslope of the vetiver hedge (Fig. 3), with little deposition in, or downslope from the hedge. The Podzol was deposited further upslope of the vetiver hedge than the Ferralsol (Fig. 3 A;B). Hussein et al. (2006) reported that the Vertisol in similar experiments was deposited up to the start of the vetiver hedge which is to be expected, as the finer sediment of the Vertisol had a lower mean settling velocity of $0.0097 \mathrm{~m} \mathrm{~s}^{-1}$ (Hussein et al., 2006) and was carried further towards the hedge by the flow, before being deposited. The settling velocity of the Ferralsol was slightly lower than that of the Podzol and so it was deposited further downstream than the Podzol (Table 1).

Fig. 3 also illustrates the time sequence of deposition for both soils. As the sediments were added, deposition started just inside the backwater region $(\sim 0.5 \mathrm{~m})$ for both soils. The Podzol sediment began to deposit at the initial start of the backwater, but deposition then primarily extended upslope and in the upstream direction. Eventually the deposition mound, itself, produced a secondary upstream backwater. The overall length of the backwater was therefore greatly extended by an additional $0.55 \mathrm{~m}$, being more than double its length at the start of the experiment (Table 2). The deposited layer of the Ferralsol was different, however, expanding both upstream and downstream of the initial start of the backwater. These different deposition patterns developed as a result of the low flow rate and its concomitant low sediment transport capacity. The very coarse material in the Podzol and Ferralsol deposited soon after entering the flow and created a secondary backwater which encouraged further deposition. Flow velocity was however sufficient to transport some of the smaller particles in the Ferralsol downstream towards the primary backwater, but as the flow velocity was further decreased these were also deposited. Overall, therefore the backwater length and its potential sediment trapping efficiency were increased when coarse sediments were added at subcritical flows. 

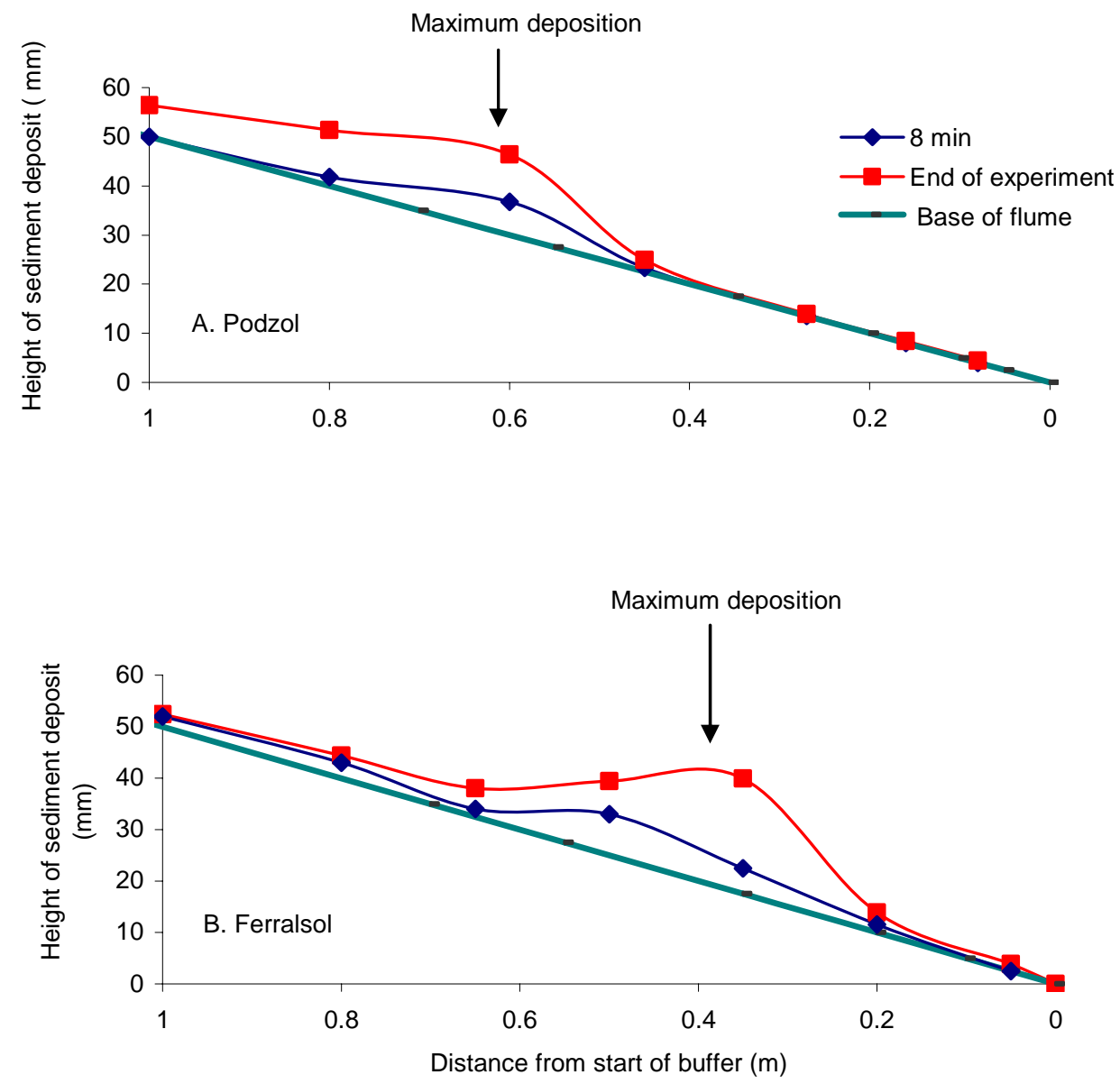

Fig. 3. Sediment deposits at different times for Podzol (A) and Ferralsol (B) with respect to distance upslope of the vetiver hedge, as measured from tags. Backwater starts at $\sim 0.5 \mathrm{~m}$ at the beginning of experiments.

Particle size distributions of deposited sediments (aggregates and primary particles) of the two soils showed an unexpected pattern (Fig. 4). Both Podzol and Ferralsol deposits showed increasing size towards the hedge with greatly increased coarse particle fractions $(2.0-4.76 \mathrm{~mm})$ at 0.55 and $0.45 \mathrm{~m}$, respectively. This is contrary to what Hussein et al. (2006) reported for a Vertisol at 5\% slope, where deposited sediments were similar in size to the inflow and there was no significant change in size distribution with distance from the vetiver hedge. Coarse aggregates/sand $(>1 \mathrm{~mm})$ were visually observed for both soils rolling downstream on the deposited bed. On reaching the zone of maximum deposition, some aggregates rolled forward along the positive slope developed at the leading edge of the mound and moved towards the vetiver hedge. An example of this is shown in Fig. 5 for the Podsol. This size increase for the Podzol and Ferralsol is confirmed by the variation in MWDs upstream of the vetiver hedge (Fig. 6). The Vertisol data of Hussein et al. (2006) is also shown in Fig. 6 for comparison. 
There is a marked increase in MWD, particularly of the Ferrasol, as it approaches the vetiver hedge. The increase in MWD is probably largest for the Ferralsol due to the relatively larger sizes (Fig. 4) and lower density of these aggregates compared to the smaller and denser primary particles in the Podzol. The larger sizes and lower density would facilitate the aggregate rolling mechanism. It is also possible that the lower settling velocity allowed the Ferralsol aggregates to be carried further in suspension before

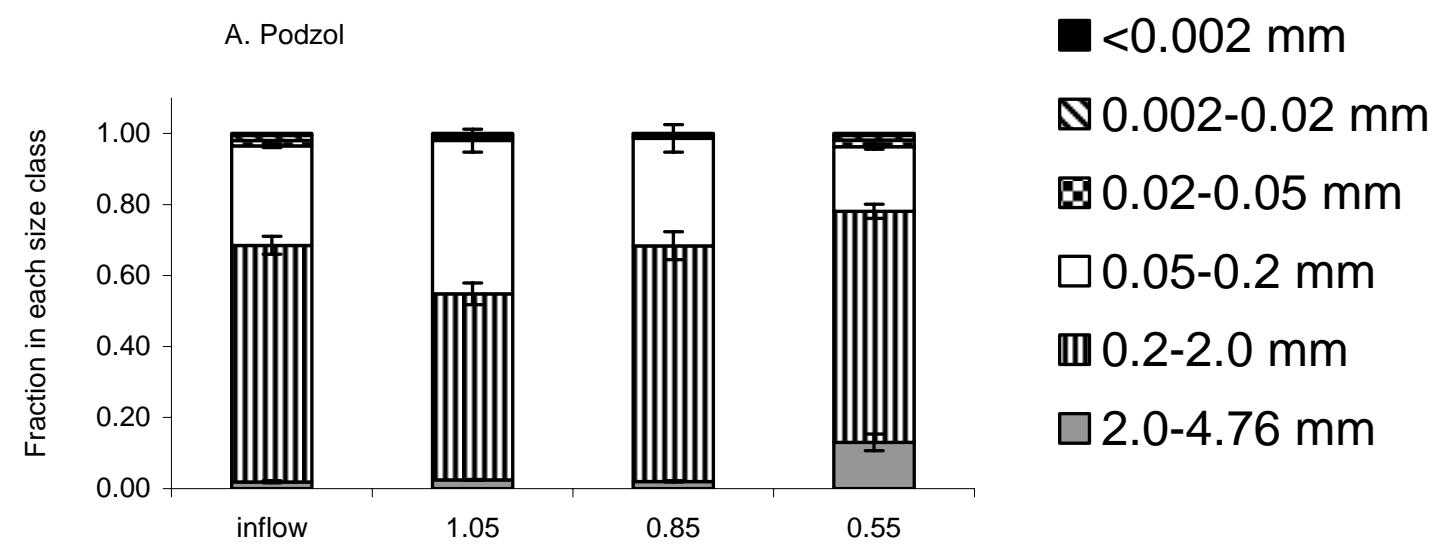

B. Ferralsol

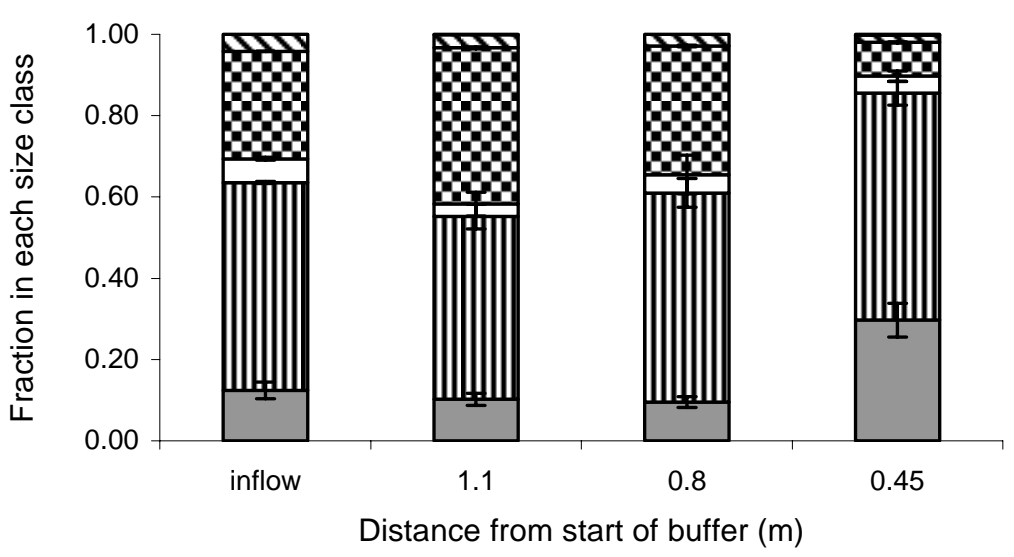

0.

Fig. 4. Particle size distribution of deposited sediment at different distances upstream of the vetiver hedge for the Podzol (A) and Ferralsol (B). Inflow is at $1.8 \mathrm{~m}$ upstream of buffer. 


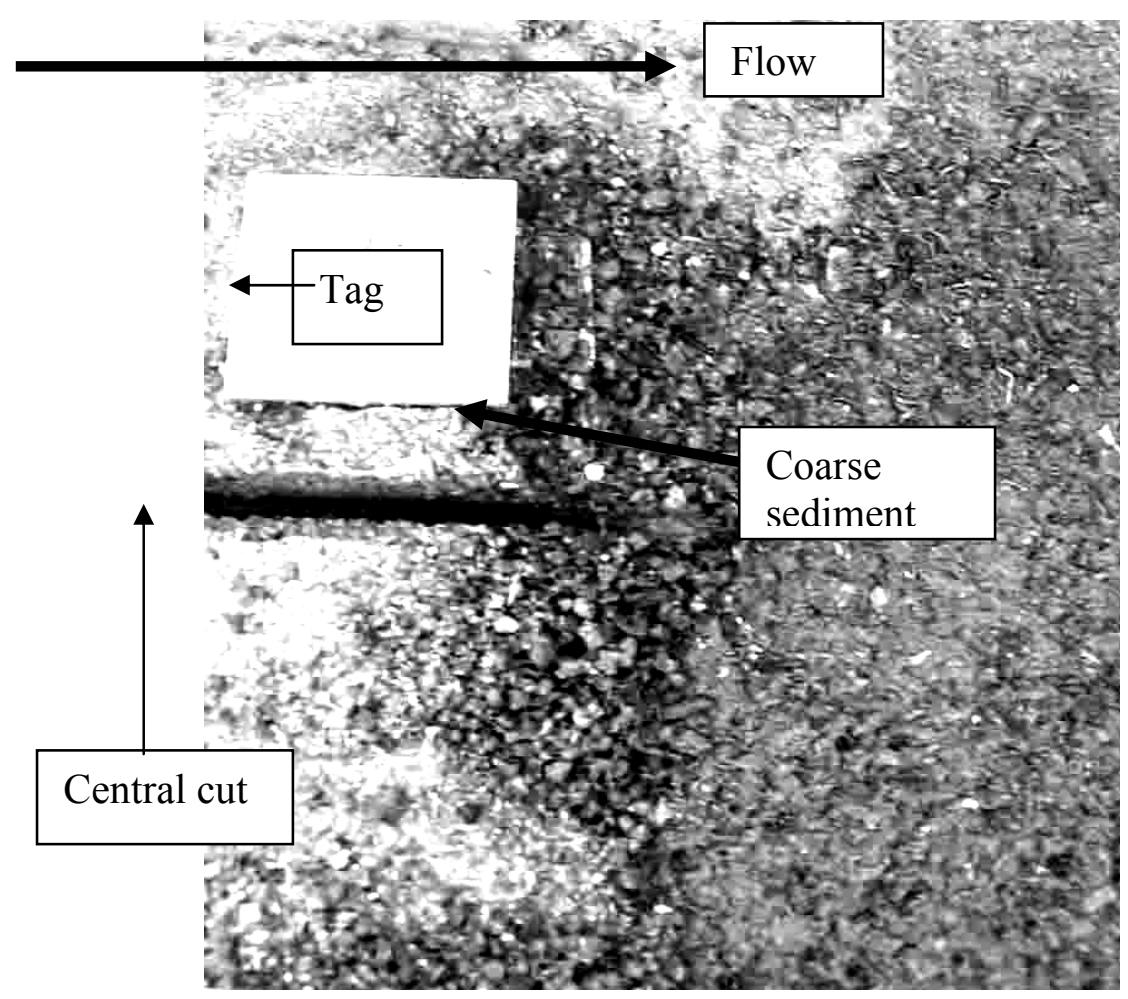

Fig. 5. Photograph looking vertically downward at coarse material on the downstream end (centre of picture) of a Podzol sediment deposit in the rainfall flume. Also shown is one of the rectangular tags ( $20 \mathrm{~mm} \times 20 \mathrm{~mm} \times 1 \mathrm{~mm}$ ) used to record progressive sedimentation. The central cut in the deposit is from the dyed board inserted to record the depth of the sediment profile. 


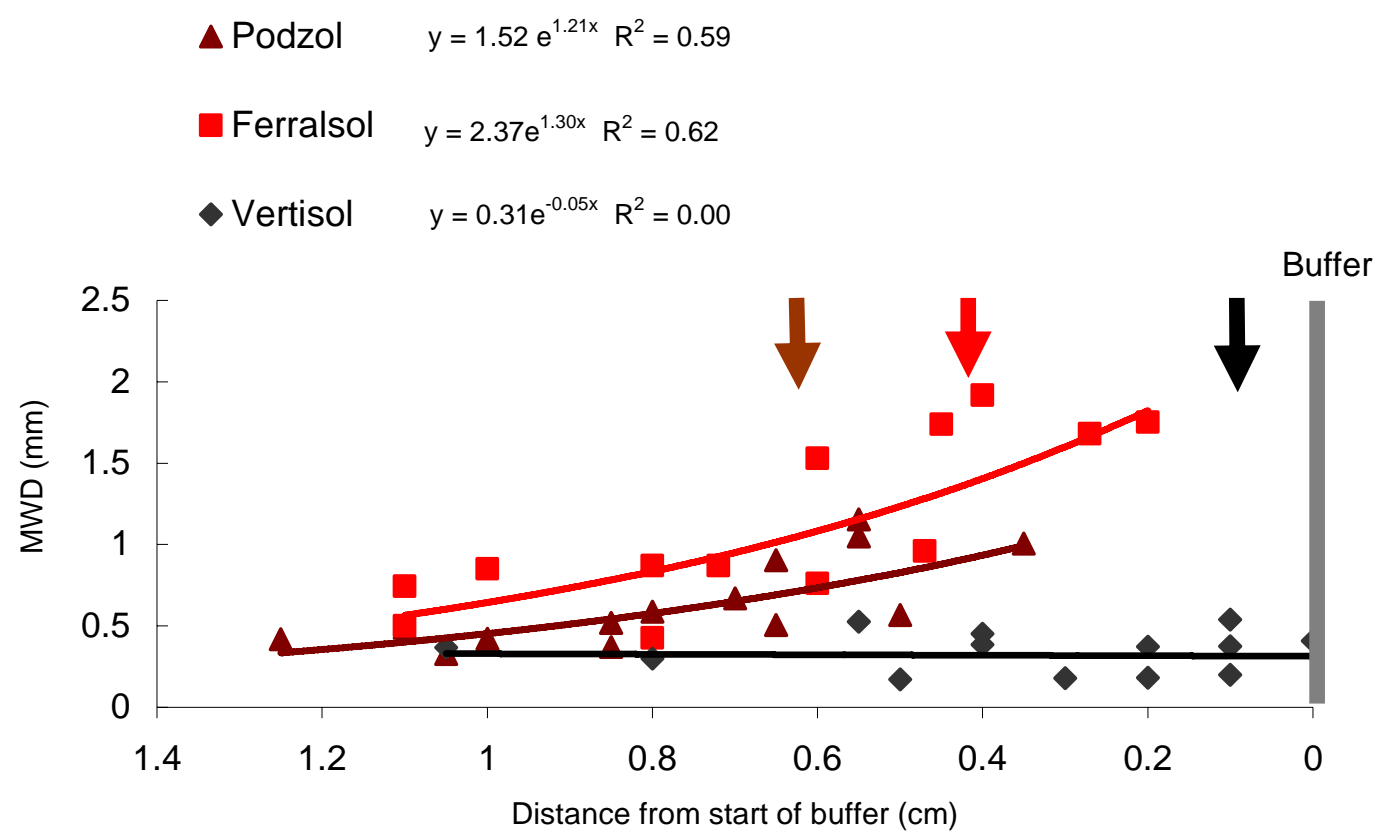

Fig. 6. Mean weight diameter (MWD) of deposited sediment with respect to distance upstream of vetiver hedge. Position of arrows indicates position of maximum deposition for each soil (Podzol -0.64 m; Ferralsol -0.40 m; Vertisol -0.06 m). Vertisol data from Hussein et al. (2007).

Our data for the Podzol and Ferralsol therefore show an increase in coarseness of deposited sediment towards the grass hedge. However, current erosion theory based on saltation and suspension transport and supported by research on faster, supercritical flows, suggests that the coarser/denser material should drop out of suspension furthest upstream from the grass hedge, at the starting position of the backwater. This is due to the higher settling velocity and decreased rate of re-entrainment of this material (as a result of decreased flow velocity). This is confirmed by the results of Dabney et al. (1995) who reported that the particle size and bulk density of a deposited silty soil (Dubbs sediment) increased as distance upstream from the hedge increased, as expected under steady-state conditions. Rose et al. (2003) likewise found the coarsest deposits near the initial hydraulic jump at 1.6 and 3.4\% slopes upstream of the hedge. However in the same set of experiments at $5.1 \%$ slope, finer material was deposited at the jump, with coarser material being measured nearest to the grass hedge.

There are a number of opposing processes which could have produced these apparently anomalous results. It is possible that as deposition proceeds and flow depth becomes shallower with time, flow will 
have greater transport capacity (effective stream power), and some deposition of coarse sediment will occur downstream of the start of the backwater. There is also a possible 'spread' of particle sizes as the backwater moves upstream during the deposition process. Our observations of the rolling (creep) of many large particles on the deposited bed of sediments, also indicate the possible involvement of bed load transport, commonly neglected in current erosion theory. This creep was observed to contribute to overall downstream movement of coarse sediment under these low flow conditions, in addition to the usual saltation and suspension processes. The possible involvement of bed load transport in erosion/deposition at subcritical flow is something that needs further investigation and possible incorporation into erosion theory. Further studies are now underway to examine this bed load transport and also to investigate flow velocities and sediment movement within grass strips, using much longer strips.

\section{Sediment in the Outflow}

Sediment concentration data in the outflow were pooled for the three replicates of each soil and are plotted against time, from the start of the sediment addition in Fig. 7. Concentrations remained fairly constant with time for the Podzol and Ferralsol with slopes of the regression equations near zero and low $\mathrm{r}^{2}$ due to the scatter of values. Mean sediment concentrations in the outflow are shown together with the sediment trapping efficiency of the vetiver hedge in Table 2. A t-test showed that there was a significant difference $(\mathrm{P}<0.01)$ in the mean sediment concentrations between the Ferralsol and Podzol, with the Ferralsol having a higher concentration due to its lower settling velocity. Hussein et al. (2006) reported a slight increase in sediment concentration with time, and a trapping efficiency of $88.4 \%$ for the Vertisol in similar experiments. The sediment trapping efficiency appears to be in the order of Podzol $>$ Ferralsol >> Vertisol, implying that the Vetiver hedge effectiveness increases with the coarseness of the sediment. The increased sediment loss for the Vertisol reported by Hussein et al. (2006) could be due to the higher proportion of fine particles, rather than the higher inflow concentration as proposed by Meyer et al. (1995), who reported that an increase in concentration of inflow sediment from 3.5 to $7.0 \%$ had little effect on sediment trapping for a fine silty soil, and for a fine loamy soil. The fine silty soil, while not quite as 'fine' in texture as the Vertisol used in the experiments of Hussein et al. (2006), is somewhat 
comparable. In contrast, the coarser soils used in this study were deposited well upstream of the vetiver hedge with little fine material remaining in suspension to move through the vetiver hedge

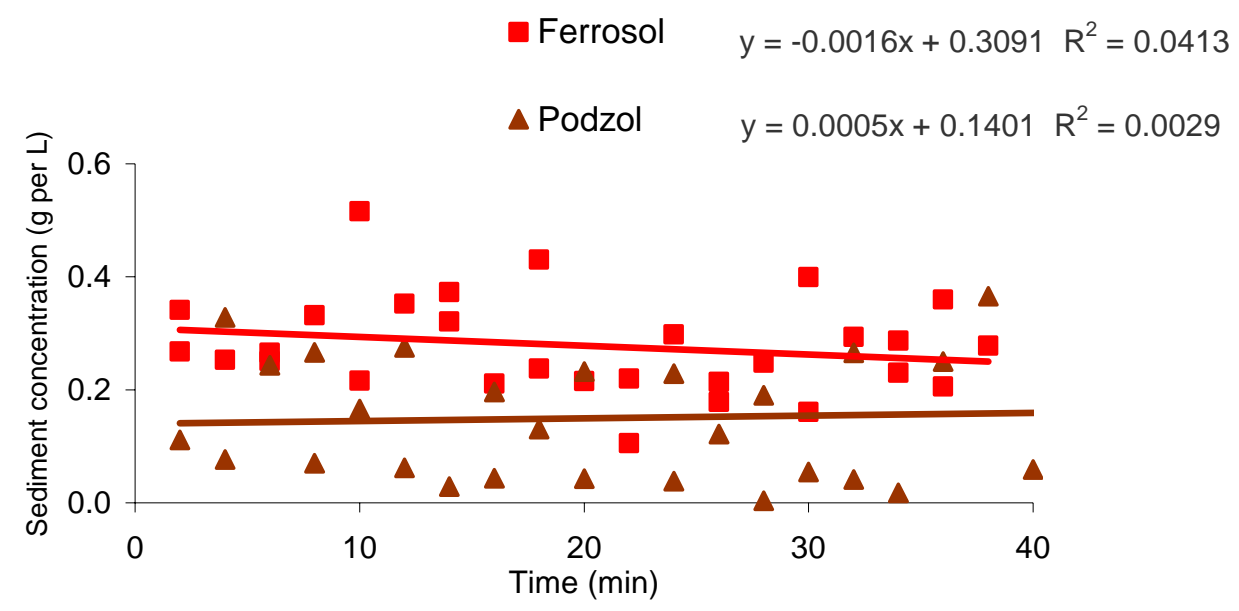

Fig. 7. Variation in sediment concentration in the outflow with time for the two soils.

Overall the hedge was very efficient as a buffer, giving a trapping efficiency of $>94 \%$ for both soils. This measurement of sediment removal includes losses upstream of, and in the hedge. Meyer et al. (1995) likewise found that sediment characteristics had a profound effect on deposition. A switchgrass hedge trapped about $70 \%$ of a coarser sandy loam soil (Smithdale) in comparison to 20 to $40 \%$ of a finer silty loam soil (Grenada) at flow rates of 0.66 to $2.62 \mathrm{~m}^{3} \mathrm{~min}^{-1} \mathrm{~m}^{-1}$. The faster flow rates (generally supercritical) used by Meyer et al. (1995) probably account for the lower sediment trapping compared to the values reported in this paper. The vetiver and switchgrass hedges used by Meyer et al. (1995) both provided similar trapping efficiencies, as both grasses have an erect growth habit with strong leaves and culms.

Field measurements on vetiver hedges have likewise shown good removal efficiencies as long as there is not channelisation of flow (McKergow et al., 2004a; b) often caused by gaps in the grass strips, or the grass is not overtopped by accumulated sediments and deep flows. Blanco-Canqui et al. (2004a) found that a $0.7 \mathrm{~m}$ switchgrass hedge reduced sediment load by $93 \%$ under $66 \mathrm{~mm} \mathrm{~h}^{-1}$ rainfall. When concentrated flow was applied through the same barrier, the switchgrass remained effective, reducing 
$93 \%$ of the sediment with flows up to $12.5 \mathrm{~L} \mathrm{~min}^{-1}$. In contrast a $0.7 \mathrm{~m}$ fescue filter strip with shorter and softer grass only trapped $64 \%$ of the sediment. This indicates the potential effectiveness of erect grass hedges in reducing sediment delivery to water bodies.

A comparison of the particle sizes in the outflow (expressed in the same size classes as Fig. 4) compared to the inflow sediment for the two soils is presented in Fig. 8. Despite the differences between the inflow sediment sizes, sediment in the outflow is primarily in the $0.002-0.2 \mathrm{~mm}$ size range for both soils. The standard errors for the Podzol outflow are relatively large, due to the very small amounts of sediment in the outflow, which made it difficult to determine particle size distribution with great accuracy. A t-test comparing size class means showed no significant differences between the Podzol and Ferralsol outflow, apart from the clay fraction $(\mathrm{P}<0.01)$, where the Podzol had a greater fraction of clay.

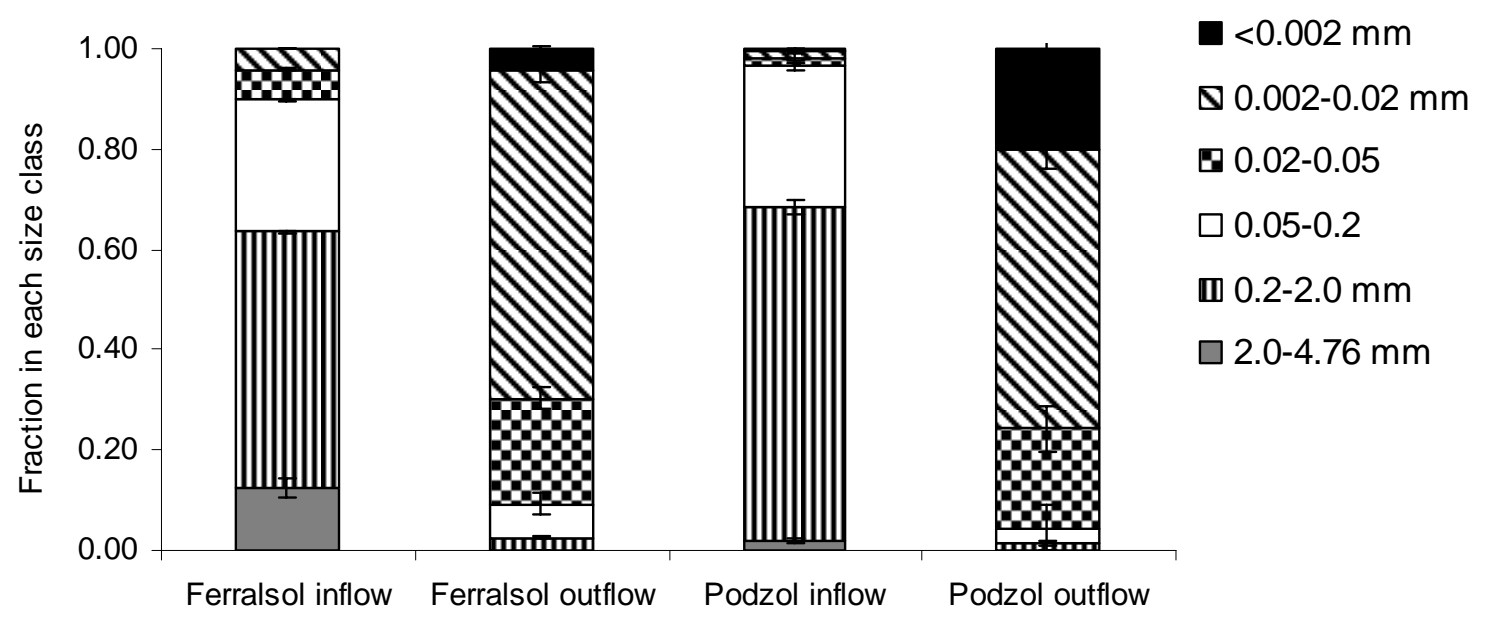

Soil type

Fig. 8. Comparison of particle sizes between inflow and outflow sediment for the two soils. Bars indicate standard errors.

As illustrated in Fig. 8, most outflow sediment consists of particles $<0.02 \mathrm{~mm}$ (equivalent to fine sand size or smaller). To compare the sediment sizes before and after the hedge, the fraction in the outflow minus the fraction in the inflow for each size class, are presented in Fig. 9 together with the Vertisol data from Hussein et al. (2006). Increasing removal of a size class from the inflow due to the vetiver hedge 
causes increasingly negative values, while large positive values indicate enrichment of that size fraction in the outflow. There were decreased coarse size fractions $(>0.02 \mathrm{~mm})$ and increased fine size fraction $(<0.02 \mathrm{~mm})$ in the outflow relative to the inflow for all soil types (Fig. 9). The greatest positive enrichment occurred for all soils in the silt -size class $(0.02-0.002 \mathrm{~mm})$ with the Podzol showing the highest enrichment in the clay-size class $(<0.002 \mathrm{~mm})$. The Ferralsol showed less enrichment of clay material, despite its potential ability to provide clay-sized particles (Table 1), because of its greater aggregate stability.

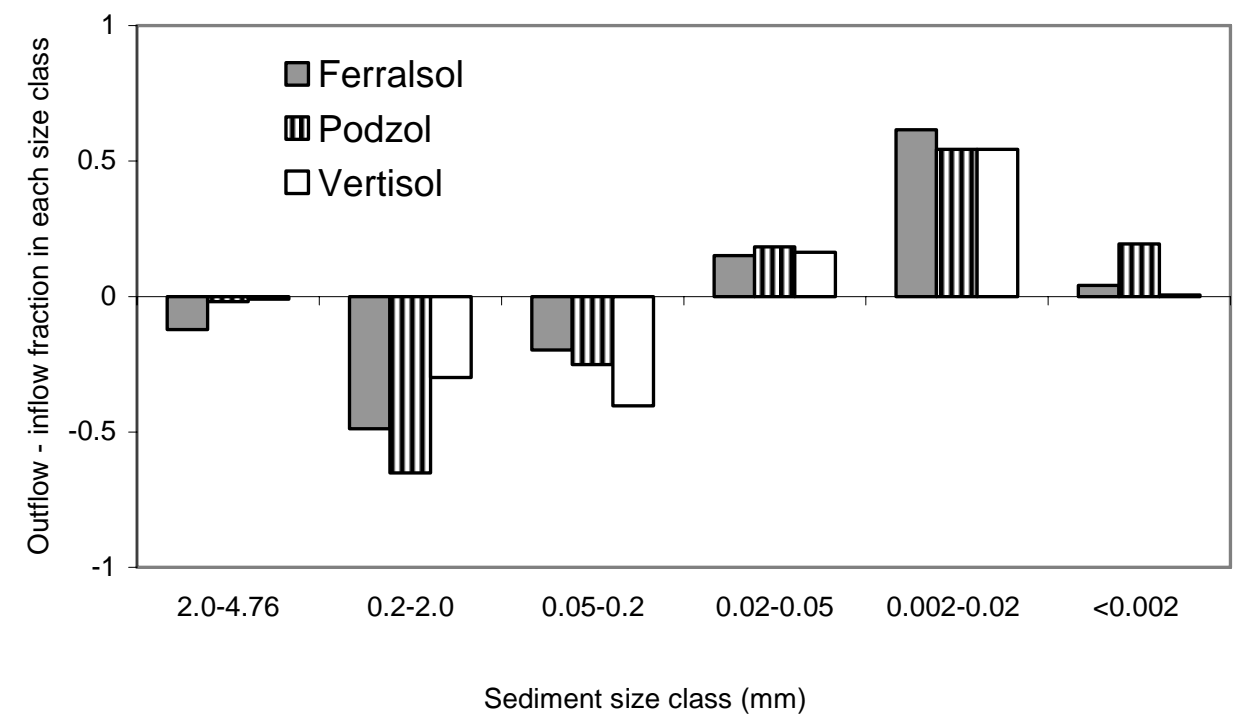

Fig .9. Potential stripping (negative values) or enrichment (positive values) of particles in the outflow, expressed as the fraction (in each size class) in the outflow - the fraction in the inflow. Data for the Vertisol are from Hussein et al. (2007) (with permission from Elsevier).

Chemicals are generally preferentially sorbed to the finer fractions in soil, or may be sorbed on the outer layers of larger aggregates (Ghadiri and Rose, 1991). These outer layers can be transformed into fine particles by mechanical breakdown or raindrop stripping (Ghadiri and Rose, 1991). While overall pollutant loads are reduced by buffers, the preferential movement of fine material $(<0.02 \mathrm{~mm})$ through vetiver hedges could have implications on the type and extent of pollutant movement to streams.

McKergow et al. (2004a) noted that typically 40 to $90 \%$ of the sediment load is reduced by buffer strips, but the trapping of particulate or sediment -associated nutrients is generally lower. Blanco-Canqui et al. (2004b) found that a $0.7 \mathrm{~m}$ switchgrass barrier reduced sediment load by $91 \%$, particulate $\mathrm{N}$ and $\mathrm{P}$ by 53 
to $67 \%$ and soluble $\mathrm{N}$ and $\mathrm{P}$ by 50 to $68 \%$. When combined with a $8 \mathrm{~m}$ fescue filter strip in which infiltration losses rather than settling losses of sediment were encouraged, sediment loads were only marginally reduced $(<5 \%)$ but particulate and soluble loads decreased by a further 5 to $50 \%$. Strips that combine erect grass hedges such as vetiver and switchgrass to promote settling with wide $(>5 \mathrm{~m})$ filter strips covered by lower, less erect grass to promote settling and infiltration are thus more effective than those with just one type of grass strip. However, if space for the buffer is limited, narrow stiff grass hedges have the ability to considerably reduce sediment loads and partially remove pollutants. Further research is underway to quantify and model the enrichment of fine sediment and its associated $\mathrm{N}$ and $\mathrm{P}$ loads through vetiver hedges.

\section{Implications for Sediment Trapping Efficiency under Subcritical versus Supercritical Flow}

The sediment trapping efficiency of grass hedges can be determined as the mass of sediment deposited/mass of inflow sediment. We earlier hypothesised that the backwater length and its sediment trapping efficiency were substantially increased when coarse sediments were added to subcritical flows. To test this hypothesis we compared our trapping efficiency data with data from three sources, two of these comprising supercritical flow experiments. The data of Dabney were derived from experiments (Froude numbers of 3.3 to 3.7 ) carried out in a flume ( $0.305 \mathrm{~m}$ width) at $5 \%$ slope using selected grass hedges including vetiver, ranging in length from 15 to $31 \mathrm{~cm}$. Rose et al. (2003) reported data from flow experiments (Froude numbers $1-2)$ at 3 slopes using a dense nail bed $(20 \mathrm{~cm}$ length) as a buffer. The data of Hussein et al. (2006) were reported for a Vertisol at 3 slopes, using a $0.3 \mathrm{~m}$ vetiver hedge and subcritical flow (Froude numbers $<1$ ). Final backwater volumes $\left(\mathrm{m}^{3}\right)$ were calculated, assuming a triangular shape, at the end of the experiments as:

$$
V_{B W}=0.5(d \times l)
$$

where $d=$ height of backwater at the start (upstream end) of the buffer and $l=$ length of backwater. An example of the final backwater is shown in Fig. 2. Trapping efficiencies were computed from masses of deposited sediment, rather than inflow-outflow measurements. To account for the different quantities of sediment added in the various data sets, $V_{B W}$ was divided by the total inflow sediment mass in $\mathrm{kg}\left(G_{i n}\right)$ to 
give a measure of backwater 'storage' of sediment. The trapping efficiencies (separated according to Froude number) are shown plotted against the relative backwater storage in Fig. 10. It can be seen from these four data sets that as Froude number progressively decreases, the $V_{B W} / G_{i n}$ increases, allowing greater settling of sediments from the flow, thus improving trapping efficiency. Thus, when flow is subcritical (Froude number $<1$ ) buffers are more efficient at trapping sediment. Our data (Table 2) suggests that the efficiency is enhanced with coarser sediments due to production of a secondary backwater. Further work is planned to test this hypothesis in the field. If this holds true, then trapping efficiencies are likely to be enhanced for the subcritical flows commonly experienced from low to medium intensity storms on low slopes.

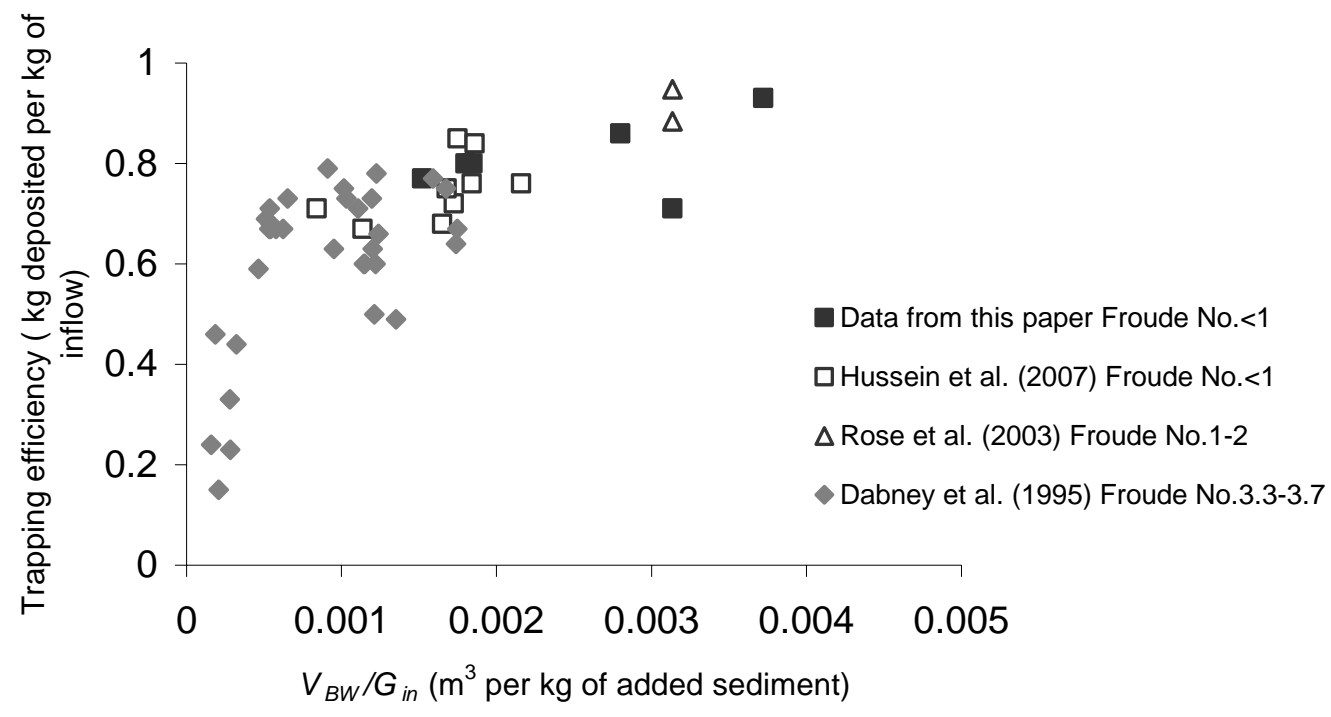

Fig.10. The effect of increase in backwater storage for deposited sediment on the buffer trapping efficiency, with respect to Froude number. Sources of data: Dabney et al. (1995), Rose et al. (2003) (with permission from Elsevier), Hussein et al. (2007) (with permission from Elsevier).

\section{CONCLUSIONS}

Results from this study on subcritical overland flow showed that a narrow vetiver grass hedge retarded flow and the resultant backwater caused sediment deposition. The deposition varied with sediment type, with the coarser Podzol sediment being deposited further upstream of the hedge than the Ferralsol, causing the Podzol backwater to more than double its original length. Sediment concentrations in the outflow remained fairly constant with time and were significantly different between the Ferralsol 
and Podzol. Particle sizes in the outflow primarily consisted of particles $<0.02 \mathrm{~mm}$ and there was

positive enrichment of fine material, particularly for the Podzol. The sediment-trapping efficiency of the hedge increased with increased coarseness of the incoming sediment and sediment concentration of the outflow was $\leq 6 \%$ of the inflow concentration. Trapping efficiencies for subcritical flow were compared with data from the literature for sub- and supercritical flow and it is suggested that trapping efficiency is improved for coarse sediments at subcritical flow, possibly because of the enhanced extension of the backwater. There was a large increase in MWD of the deposited sediment towards the buffer, especially for the Ferralsol, indicating an increase in the overall coarseness of the deposit. In contrast, other researchers examining supercritical flow have noted that sediment deposits are finer towards the buffer. There are a number of processes which could have caused this anomaly but our visual observations of the rolling, or creep, of coarse particles along the surface of the deposition bed following initial deposition, suggest that bedload transport could be an important transport mechanism at subcritical flow. Further work is underway to assess if this bedload movement occurs through the buffer and if so, the implications for sediment and nutrient/pollutant movement through grass hedges.

\section{REFERENCES}

Australian Standards. 1995. AS 12898.3.6.2-1995. Method 3.6.2 Soil classification tests- determination of the particle size distribution of a soil - analysis by sieving in combination with hydrometer analysis (subsidiary method). Government of Australia.

Barros, A.P., and J.D. Colello. 2001. Surface roughness for shallow overland flow on crushed stone surfaces. J.Hydraulic Eng. January:38-52.

Black, A.S., and S.A. Waring. 1976. Nitrate leaching and adsorption in a Krasnozem from Redland Bay, Queensland. Aust. J. Soil Res. 14:171-180.

Blanco-Canqui, H., C.J. Gantzer, S.H. Anderson, and E.E. Alberts. 2004a. Grass barriers for reduced concentrated flow induced soil and nutrient loss. Soil Sci. Soc. Am. J. 68:1963-1972.

Blanco-Canqui, H., C.J. Gantzer, S.H. Anderson, E.E. Alberts, and A.L. Thompson. 2004b. Grass barriers and vegetative filter strip effectiveness in reducing runoff, sediment, nitrogen and phosphorus loss. Soil Sci. Soc. Am. J. 68:1670-1678.

Cheng, N.S. 1997. Simplified settling velocity formula for sediment particles. J. Hydraulic Eng. 123:149-152.

Dabney, S.M., L.D. Meyer, W.C Harmon, C.V. Alonso, and G.R Foster. 1995. Depositional patterns of sediment trapped by grass hedges. Trans. ASAE 38:1719-1729.

Dalton, P.A. 1997. Application of vetiver grass hedges to erosion control on the cropped flood plain of the Darling Downs. Master of Engineering Thesis, Faculty of Engineering and Surveying, University of Southern Queensland, Australia.

Emmett, W.W. 1978. Overland flow. Chapter 5 p.145-176. In M.J. Kirkby (ed.) Hillslope hydrology. Wiley, New York.

FAO. 1998. World Reference Base for Soil Resources. World Soil Resources Report 84. FAO, Rome. 
Finnemore, E.J., and J.B. Franzini. 2001. Fluid Mechanics with Engineering Applications. McGraw Hill, Boston, MA., U.S.A.

Ghadiri, H., and C.W. Rose. 1991. Sorbed chemical transport in overland flow: II. Enrichment ratio variation with erosion processes. J. Environ. Qual. 20:634-641.

Ghadiri, H., C.W. Rose, and W.L. Hogarth. 2001. The influence of grass and porous barrier strips on runoff hydrology and sediment transport. Trans. ASAE 44:259-268.

Gharabaghi, B., R.P Rudra, H.R.. Whitely, and W.T. Dickinson. 2000. Sediment-removal efficiency of vegetative filter strips. Annual Research Report p. 32-40. Guelph Turfgrass Institute, Guelph. Ontario, Canada.

Gilley, J.E., B. Eghball, L.A. Kramer, and T.B.Moorman. 2000. Narrow grass hedge effects on runoff and soil loss. J. Soil Water Conserv. 55:190-196.

Hussein, J., B. Yu, H. Ghadiri, and C.W. Rose. 2006. Prediction of surface flow hydrology and sediment retention upstream of a vetiver buffer strip for a Vertisol at three slopes. J. Hydrol. 338:261-272.

Loch, R.J., and C.J. Rosewell. 1992. Laboratory methods for measurement of soil erodibilities (K factors) for the Universal Soil Loss Equation. Aust. J. Soil Res. 30:233-248.

McKergow, L.A., I.P. Prosser, R.B. Grayson, and D. Heiner. 2004a. Performance of grass and rainforest riparian buffers in the wet tropics, Far North Queensland. 2. Water quality. Aust. J. Soil Res. 42:485-499.

McKergow, L.A., I.P. Prosser, R.B. Grayson, and D. Heiner. 2004b. Performance of grass and rainforest riparian buffers in the wet tropics, Far North Queensland. 1. Riparian Hydrology. Aust. J. Soil Res. 42:473-484.

Metcalfe, O., P. Truong, and R. Smith. 2003. Hydraulic characteristics of vetiver hedges in deep flows. Proc. Third Int. Conf. Vetiver, Vetiver and Water, Guangzhou, China 6-9 October 2003. Vetiver Organisation.

Meyer, L.M., S.M. Dabney, and W.C. Harmon. 1995. Sediment trapping effectiveness of stiff grass hedges. Trans. ASAE 38:809-815.

Newham, L.T.H., J.C. Rutherford, and B.F.W. Croke. 2005. A conceptual model of particulate trapping in riparian buffers. CSIRO Land and Water Technical Report 21/05. CSIRO Land and Water Canberra, Australia.

Rayment, G.E., and F.R. Higginson 1992. Australian laboratory handbook of soil and water chemical methods. Australian Soil and Land Survey Handbook. Series 3. 330pp.

Rose, C.W., W.L. Hogarth, H. Ghadiri, J. Parlange, and A.E.A Okom. 2002. Overland flow to and through a segment of uniform resistance. J. Hydrol 255:134-150.

Rose, C.W., B. Yu, W.L. Hogarth, A.E.A. Okom, and H. Ghadiri. 2003. Sediment deposition from flow at low gradients into a buffer strip - a critical test of re-entrainment theory. J. Hydrol 280:33-51

Soil Survey Staff. 1999. Soil Taxonomy, a basic system of soil classification for making and interpreting soil surveys. Second Edition. USDA-SCS, US Govt. Printing Office, Washington, D.C.

Truong, P.N.V. 1999. Vetiver grass technology for flood and stream bank erosion control. Proc. Int. Workshop on Vetiver Bioengineering technology for Erosion and Sediment Control and Civil construction stabilisation, Nanchang, China. 19-21 October 1999, Vetiver Organisation .

Van Bavel, C.H.M. 1950. Mean weight diameter of soil aggregates as a statistical index of aggregation. Soil Sci. Soc. Am. Proc. 14:20-23. 